\title{
Urban planning and public health in Africa. Historical, theoretical and practical dimensions of a continent's water and sanitation problematic
}

\section{Carlos Nunes Silva}

To cite this article: Carlos Nunes Silva (2013) Urban planning and public health in Africa. Historical, theoretical and practical dimensions of a continent's water and sanitation problematic, Planning Perspectives, 28:3, 508-510, DOI: 10.1080/02665433.2013.800710

To link to this article: https://doi.org/10.1080/02665433.2013.800710

曲 Published online: 20 Jun 2013.

Submit your article to this journal

Џ Article views: 141 


\title{
Notes
}

1. John Patrick Leary, 'Detroitism.' Guernica Magazine (New York), 15 January 2011. Accessed January 1, 2013. http://www.guernicamag.com/features/leary_1_15_11/

2. 'The Incredible Shrinking City.' New York Times, 3 March 2011. Accessed January 1, 2013. http:// www.nytimes.com/roomfordebate/2011/03/28/the-incredible-shrinking-city

3. Jason Hackworth, The Neoliberal City: Governance, Ideology, and Development in American Urbanism. Ithaca, NY: Cornell University Press, 2007, p. 3.

\author{
Ryan Reft \\ University of California, San Diego \\ rreft@ucsd.edu \\ (C) 2013, Ryan Reft
}

http://dx.doi.org/10.1080/02665433.2013.800709

\begin{abstract}
Urban planning and public health in Africa. Historical, theoretical and practical dimensions of a continent's water and sanitation problematic, by Ambe J. Njoh, Farnham, Ashgate, 2012, 237 pp., £55 (hardcover)
\end{abstract}

Public health and sanitation problems in Africa are frequently seen as a direct outcome of scarce financial resources. The book 'Urban Planning and Public Health in Africa' offers a different interpretation, questions long-held views about this issue, and explains how non-financial factors are the source of sanitation problems in Africa. Modernist urban planning, and the unsustainable conventional technologies associated with it, is viewed as the key factor responsible for the current sanitation problems in African cities.

The book is divided into three main sections. The first part deals with the colonial past, the second discusses the hygiene and sanitation conditions characterizing different sub-regions of Africa, and the last discusses the relation between colonialism and public health and the strategies for a sustainable hygiene and sanitation policy in Africa.

The first section of the book is an important addition to the literature on colonial urban planning in Africa. It is mainly focused on Anglophone and Francophone African countries, with very short or almost no references to other colonial presences, such as that of Portugal. In Chapter 1 ('A Brief History of Public Health and the Built Environment'), Ambe Njoh summarizes the history of public health as a critical issue of human settlement development everywhere and in all historical periods with the aim to borrow lessons from the past to be applied by contemporary and future urban planning practice in Africa. This is followed in Chapter 2 ('The State, Ideology, Health and Built Space in Africa') by a discussion of the history of sanitation policy in Africa, challenging the widely held view that it was the European colonial authorities that introduced hygiene and sanitation elements of spatial design in Africa.

After describing the indigenous origins of public health policies in pre-colonial Africa, Ambe Njoh analyses the colonial (e.g. British and French, mainly) and post-colonial hygiene 
and sanitation initiatives. The next chapter ('Town Planning, Public Health and the Colonial Project') examines the health and sanitation component of colonial urban planning in Africa as part of a concern for the health and wellbeing of Europeans, and not directly with that of the African population, as a result of the racially segregated urban zoning applied in colonial cities. This is followed, in Chapter 4 ('Racism Versus Health Concerns as the Rationale for Racial Segregation'), by the argument that race ideology rather than the limited knowledge of tropical diseases lay at the basis for racial segregation in colonial cities, a perspective based on ample evidence from the five sub-regions of Africa (North, West, Centre, East and South). A number of views on this issue are scrutinized and contested, such as the 'Natural tendency thesis', the 'European medieval origins hypothesis', the 'Preservation of European culture hypothesis', and the 'European health promotion thesis'. The chapter also shows how, after independence, the new political leadership continued to implement a segregationist urban policy, no longer based on race but on socio-economic status. In Njoh's opinion this is a direct outcome of modern urbanism, in particular of its zoning principles. This section ends with Chapter 5 ('Public Health Implications of Modernist Planning') in which the relation between Modern Urbanism and public health and sanitation policy in Africa is discussed, as well as the reasons why the modern discourse on urbanism was important for the European cultural project in the colonies, and how this discourse on urbanism continues to be important in contemporary postcolonial urban planning in Africa.

The second part of the book describes and discusses the current state of public health in Africa, within each of its regions, avoiding therefore the usual over-generalization of Africa's socio-economic problems. Each chapter assesses the prevailing hygiene and sanitation conditions and the progress towards the relevant target of the Millennium Development Goals, revealing huge regional disparities in the continent.

In Chapter 9 ('Solid Waste Disposal and Sanitation Technologies, and Determinants of Access to Improved Sanitation') the relation between colonial experience and access to water and sanitation services and facilities is tested using quantitative statistical methods. In the last chapter ('Sustainable Hygiene and Sanitation Strategies'), the author shows how the use of imported solutions for public health problems in Africa, instead of local ones based on indigenous knowledge, has been responsible for the maintenance of huge public health problems in African cities. He argues that the solution for this problem requires, among other actions, a better use of indigenous knowledge in urban planning and a more effective engagement of local citizens in the urban planning process.

The book gives a highly uneven picture, not only between colonial powers (e.g. British and French) but also within the same colonial empire between specific colonies or governors. The size of the European population in the colony and the level of organization of the African population also made a huge difference in the degree of segregation introduced by urban planning, as did the length of the colonial presence.

The book challenges the belief that European colonial authorities introduced hygiene and sanitation elements of spatial design in Africa, providing evidence on hygiene and sanitation legislation in pre-colonial Africa, and argues that the indigenous knowledge applied in the organization of human settlements in the pre-colonial period should be considered in contemporary public health strategies in Africa. It contests that the limited knowledge of tropical diseases was the basis for racial segregation. On the contrary, Ambe Njoh brings evidence that it was race ideology that was responsible for racial segregation at the time, and not the intended 
prophylaxis against malaria. With the end of colonialism, the new leadership inherited, sharpened and implemented these colonial segregationist planning policies. Now they were based on socio-economic rather than racial criteria, but they had similar consequences for public health. The link between colonialism and its racial residential segregation, replaced by socioeconomic status after independence, on one side, and poor living and health conditions in African cities, on the other, leaves no doubt that any attempt to improve urban living and health conditions will not succeed without deep changes in these segregated urban structures. Njoh's evidence suggests that planning and health authorities in African cities would do well to blend together foreign and indigenous human settlements strategies, as well as environmentally, economically and socio-culturally sustainable practices.

Njoh emphasizes the influence of what he calls colonial 'modernist planning' in the creation of these segregated spatial structures. The author seems to refer implicitly the Congrès Internationaux d'Architecture Moderne (CIAM) discourse on Urbanism ${ }^{1}$ and the principles of its Athens Charter. However, the influence of CIAM's principles in African cities is obvious above all in the years after World War II. What prevailed during most of the first half of the twentieth century was the Garden City model, in the three main planning cultures in subSaharan Africa - Francophone, Anglophone and Lusophone. For that reason, while agreeing with Njoh when he identifies racist ideology as the motivating factor behind racial residential segregation, I do not concur entirely with his argument that zoning, an instrument of modern urbanism, was responsible for racial segregation. Functional and social separation occurs as a consequence of zoning but not necessarily along racial lines. If that happened it was due to racist ideology. It is thus indispensable to replace building codes inherited from the colonial period, as well as colonial planning laws, to develop and experiment new urban planning models, based on arguments similar to those presented by Roy and Watson ${ }^{2}$ in order to address current public health needs in African cities that are characterized by diversity and deep difference.

\section{Notes}

1. Mumford, he CIAM Discourse on Urbanism, 1928-1960.

2. Roy, Post-Liberalism, 92-102; Watson, Deep Difference, 31-50.

\section{Bibliography}

Mumford, Eric. The CIAM Discourse on Urbanism, 1928-1960. Cambridge, MA: The MIT Press, 2000. Roy, Ananya. "Post-Liberalism: On the Ethico-Politics of Planning." Planning Theory 7, no. 1 (2008): $92-102$.

Watson, Vanessa. "Deep Difference: Diversity, Planning and Ethics.” Planning Theory 5, no. 1 (2006): $31-50$.

Carlos Nunes Silva Institute of Geography and Spatial Planning, University of Lisbon cs@campus.ul.pt

(C) 2013, Carlos Nunes Silva http://dx.doi.org/10.1080/02665433.2013.800710 